\title{
Tindak Tutur llokusi Asertif, Direktif, Ekspresif, Komisif, dan Deklaratif pada Program Gelar Wicara Mata Najwa
}

\author{
Artati $^{1}$, Dian Eka Chandra Wardhana ${ }^{2}$, Rokhmat Basuki ${ }^{3}$ \\ Program Magister Pendidikan Bahasa Indonesia, Universitas Bengkulu \\ Email: artatidahir@yahoo.com ${ }^{1}$,dec.wardhana@unib.ac.id ${ }^{2}$, \\ rokhmatbasuki@gmail.com ${ }^{3}$ \\ Corresponding email: artatidahir@yahoo.com ${ }^{* 1}$
}

\begin{abstract}
The purpose of this research was to describe the assertive, directive, expressive, commissive, and declarative illocutionary speech acts on the December 2018 Mata Najwa talk show program. The research method used is descriptive qualitative method. Data collection techniques using documentation techniques obtained from the Mata Najwa video program December 2018 edition taken using a handphone. Data analysis techniques are done by reducing data, presenting data, interpreting data, and conclusions. Test the validity of the data by validating pragmatic experts and member checks. The type of illocutionary speech acts in the Mata Najwa talk show program mostly use expressive speech acts that contain congratulations, thanks, praise, and criticism. Assertive speech acts aim to say, report, and mention. The directive speech acts contain speech of asking, asking, demanding, suggesting, and opposing. Commissive speech acts contain speech promising, swearing, and threatening. Then, declarative speech acts contain speech deciding, canceling, prohibiting, permitting, and forgiving. From the results of this study, it shows that in making talk show programs it is better to use variations in illocutionary speech acts and the most dominant percentage of their use should use expressive speech acts so that events are more interesting.
\end{abstract}

Keywords: speech act, Mata Najwa talk show program

\begin{abstract}
Abstrak
Penelitian ini bertujuan untuk mendeskripsikan tindak tutur ilokusi asertif, direktif, ekspresif, komisif, dan deklaratif pada pada program gelar wicara Mata Najwa edisi Desember 2018. Metode penelitian yang digunakan yaitu metode deskriptif kualitatif. Teknik pengumpulan data menggunakan teknik dokumentasi yang diperoleh dari video acara Mata Najwa edisi Desember 2018 yang diambil menggunakan gawai. Teknik analisis data dilakukan dengan cara mereduksi data, menyajikan data, interpretasi data, dan kesimpulan. Uji keabsahan data dengan cara validasi pakar pragmatik dan member check. Jenis tindak tutur ilokusi pada pada program gelar wicara Mata Najwa sebagian besar menggunakan tindak tutur ekspresif yang berisi ucapan selamat, terima kasih, memuji, dan mengkritik. Tindak tutur asertif bertujuan untuk mengatakan, melaporkan, dan menyebutkan. Tindak tutur direktif berisi tuturan menyuruh, memohon, menuntut, menyarankan, dan menentang. Tindak tutur komisif berisi tentang tuturan berjanji, bersumpah, dan mengancam. Kemudian, tindak tutur
\end{abstract}


deklaratif berisi tentang tuturan memutuskan, membatalkan, melarang, mengizinkan, dan memberi maaf. Dari hasil penelitian ini, menunjukkan bahwa dalam membuat program gelar wicara atau talk show sebaiknya menggunakan variasi tindak tutur ilokusi dan persentase penggunaannya yang paling dominan sebaiknya menggunakan tindak tutur ekspresif sehingga acara lebih manarik.

Kata kunci: tindak tutur, program gelar wicara Mata Najwa

\section{PENDAHULUAN}

Berkomunikasi antara manusia menggunakan bahasa bertujuan agar saling memahami maksud dan tujuan antara penutur dengan mitra tutur (Kusmiarti, 2020:207-208). Oleh karena itu, bahasa merupakan komponen penting yang tidak dapat dipisahkan dari masyarakat, bahkan bahasa merupakan milik masyarakat pemakainya yang diwujudkan dalam bentuk tindak tutur (Noermanzah, 2019:307308). Tindak tutur dapat berbentuk permohonan, permintaan maaf, keluhan, pujian, undangan atau janji. Chaer (2010:27) menjelaskan tindak tutur sebagai tuturan dari seseorang yang bersifat psikologis dan yang dilihat dari makna tindakan dalam tuturan itu. Menurut Cummings (2007:362), tindak tutur merupakan kategori yang yang kaya dengan beberapa fenomena pragmatik yang bisa dikaji. Berkomunikasi menggunakan media wacana, wujud wacana dapat berupa rangkaian ujar dalam bentuk tuturan lisan maupun tulisan (Syafryadin dkk., 2020:3270-3271). Komunikasi lisan merupakan komunikasi menggunakan kata-kata lisan langsung kepada lawan bicaranya, pada kondisi para personal ataupun individu berhadapan langsung. Seperti pada saat berkomunikasi dengan tatap muka langsung atau dengan alat elektronik seperti telepon, telivisi, dan lain-lain.

Tidak heran banyaknya stasiun televisi di Indonesia yang berlomba-lomba menyajikan progam acara televisi yang bagus demi meningkatkan rating tontonan dari pemirsa setianya. Salah satunya adalah progam acara televisi Mata Najwa. Acara Mata Najwa merupakan salah satu program acara televisi yang menampilkan banyak berita mulai dari politik, pendidikan hingga budaya. Dengan karakter pembawa acara yang spontan ketika bertutur dan apa adanya seringkali mengundang tawa atau humoris yang menjadikan acara ini semakin menarik. Di acara Mata Najwa tersebut memiliki pernyataan-pernyataan yang ditemukan bermakna ilokusi. Dengan demikian, secara pragmatis setidak-tidaknya ada tiga jenis tindakan yang dapat diwujudkan oleh seorang penutur. Chaer (2010:27), mengklasifikasikan kategori tindak tutur menjadi tiga tindak tutur yang dimaksud adalah tindak tutur lokusi, tindak tutur ilokusi, dan tindak tutur perlokusi.

Menurut Sarle (dalam Handayani, 2016:306) dan Saptani (2015:1-2) juga mengklasifikasikan tindak tutur menjadi tiga kategori yaitu tindak tutur tersebut lokusi, ilokusi, dan perlokusi. Tindak tutur lokusi adalah tindakan menyatakan atau mengucapkan sesuatu dengan kata dan makna kalimat sesuai dengan makna itu (Lismayanti \& Aswadi,. 2018:101). Tindak tutur ilokusi adalah tindak melakukan sesuatu, yakni berbicara tentang maksud, fungsi atau daya ujaran yang bersangkutan (Mirfat, 2019:89; Novianti, 2017:129). Tindak perlokusi adalah efek yang dihasilkan penutur dengan mengatakan sesuatu (Insani \& Sabardila, 2016:176). Berdasarkan ilokusi tersebut dalam program acara Mata Najwa menyajikan jenis-jenis tindak tutur sehingga informasi yang ingin disampaikan melalui media tersebut mudah dipahami, karena mempunyai tujuan untuk menghibur 
dan bermanfaat bagi penonton. Hal tersebut terdapat pada dokumentasi berbagai macam tindak tutur. Penutur dan mitra tutur pada saat penayangan acara tersebut.

Di dalam komunikasi tidak ada tuturan tanpa situasi tutur. Situasi tutur sangat penting di dalam pragmatik. Maksud tuturan yang sebenarnya hanya dapat diidentifikasi melalui situasi tutur yang mendukungnya. Menurut Wijana \& Rohmadi (2011:15) aspek situasi tutur terbagi atas lima bagian, meliputi penutur, lawan tutur, konteks tuturan, tujuan tuturan, dan tuturan sebagai bentuk tindakan atau aktivitas. Tuturan sebagai produk tindak verbal. Dalam situasi tutur akan berkaitan pula dengan konteksnya. Menurut Kleden (dalam Sudaryat, 2011:141) menjelaskan bahwa konteks adalah ruang dan waktu yang spesifik yang dihadapi seseorang atau kelompok. Penulis mengambil hasil penelitian relevan dari Ardianto (2013) dengan judul "Tindak Tutur Direktif Guru dalam Wacana Interaksi Kelas Anak Tunarungu". Persamaan dalam penelitian relevan yang penulis ambil terdapat pada komunikasi atau tindak tutur. Sedangkan perbedaannya terdapat pada sumber data. penulis pengambil data dari acara Mata Najwa, sedangkan penelitian relevan mengambil data dari komunikasi yang terjadi di dalam kelas. Penelitian relevan yang penulis ambil bermaanfaat sebagai acuan dan perbandingan dalam penulisan hasil analisis. Penelitian ini bertujuan untuk mendeskripsikan tindak tutur ilokusi acara Mata Najwa Edisi Desember 2018. Dengan harapan dapat memberikan sumbangsih dalam pengembangan ilmu pragmatik dan dapat dijadikan contoh dalam mengajar materi kemampuan berbicara dalam bentuk talkshow atau gelar wicara kepada siswa sekolah menengah atas.

\section{METODE}

Metode yang digunakan yaitu metode deskriptif kualitatif. Metode yang digunakan berbentuk deskripsi tuturan-tuturan yang mengandung bentuk tindak tutur dalam acara Mata Najwa edisi Desember 2018. Analisis yang digunakan yaitu analisis isi berhubungan dengan dialog dalam acara Mata Najwa. Jenis metode yang digunakan adalah metode kualitatif. Metode kualitatif lebih serasi digunakan dalam penelitian sastra, karena metode kualitatif secara keseluruhan memanfaatkan caracara penafsiran dengan menyajikan dalam bentuk deskriptif. Kegiatan pengumpulan data merupakan bagian penting dari proses penelitian, karena tujuan utama dari penelitian adalah mendapatkan data. Penelitian ini menggunakan teknik dokumentasi. Di dalam melaksanakan metode dokumentasi, yang bersumber dari acara Mata Najwa edisi Desember 2018. Metode pengumpulan data menggunakan metode simak, yaitu dengan menyimak tindak tutur yang digunakan dalam kegiatan berkomunikasi dalam acara Mata Najwa edisi Desember 2018.

Metode simak merupakan metode dalam penyediaan data yang dilakukan dengan cara menyimak penggunaan atau pemakaian bahasa. Teknik simak yang digunakan pada penelitian ini adalah teknik simak bebas libat cakap. Teknik ini merupakan teknik yang tidak melibatkan peneliti dalam tuturan, artinya peneliti tidak ikut serta dalam pembicaraan orang-orang yang berbicara. Analisis data dalam penelitian ini menggunakan teknik analisis dengan langkah-langkah sebagai berikut.

1. Melakukan kegiatan transkripsi data audio visual menjadi tertulis dari video tayangan Mata Najwa edisi Desember 2018.

2. Memberi kode pada setiap data.

3. Mengidentifikasi percakapan-percakapan yang mengandung tindak tutur ilokusi (asertif, direktif, ekspresif, komisif, dan deklarasi). 
4. Mengelompokkan berbagai percakapan acara Mata Najwa mengandung tindak tutur ilokusi (asertif, direktif, ekspresif, komisif, dan deklarasi) pengelompokan data berdasarkan tindak tutur ilokusi (asertif, direktif, ekspresif, komisif, deklarasi) berbahasa yang dibentuk.

Uji keabsahan data dalam penelitian ini dilakukan dengan cara validasi pakar pragmatik dan member check. Validasi pakar pragmatik adalah dosen yang mengampu Matakuliah Pragmatik, sedangkan member check dilakukan ketika menganalisis setiap temuan tindak tutur dikaitkan dengan kebenaran pada teori yang digunakan.

\section{HASIL}

Hasil penelitian menunjukkan penggunaan variasi tindak tutur ilokusi, mulai dari tindak tutur asertif, direktif, ekspresif, komisif, dan deklarasi. Langkah awal dalam menganalisis data, yaitu mengidentifikasi data percakapan-percakapan yang mengandung bentuk tindak tutur ilokusi (asertif, direktif, ekspresif, komisif, dan deklarasi) dalam acara Mata Najwa Edisi Desember 2018. Langkah ini dengan cara membaca satu per satu hasil transkip video Mata Najwa dengan menandainya dalam tabulasi data.

Klasifikasi yang dilakukan dalam penelitian ini adalah menggolongkan data yang telah tersusun atau yang sudah dipilih dalam reduksi data. Klasifikasi menggolongkan menjadi lima yaitu tindak tutur asertif, direktif, ekspresif, komisif, dan deklarasi. Penelitian deskriptif kualitatif dalam menyajikan datanya dapat dilakukan dalam bentuk uraian singkat, bagan, hubungan antar kategori, dan sejenisnya. Dalam penelitian ini penyajian data digunakan untuk menyajikan hasil analisis tindak tutur asertif, direktif, ekspresif, komisif ,dan deklarasi acara Mata Najwa.

Sesuai dengan fokus penelitian ini, hasil penelitian menunjukkan bahwa tindak tutur ilokusi yang terdiri dari tindak tutur asertif mencakup tiga hal yakni: (1) mengatakan, (2) melaporkan dan (3) menyebutkan. Tindak tutur direktif mencakup lima hal yakni: (1) menyuruh, (2) memohon, (3) menuntut, (4) menyarankan, dan (5) menentang. Selanjutnya, tindak tutur ekspresif yang mencakup empat hal yakni: (1) ucapan selamat, (2) terima kasih, (3) memuji dan (4) mengkritik. Tindak tutur komisif mencakup dari tiga bagian yaitu: (1) berjanji, (2) bersumpah dan (3) mengancam. Bagian terakhir yaitu tindak tutur deklarasi terdiri dari lima bagian yaitu: (1) memutuskan, (2) membatalkan, (3) melarang, (4) mengizinkan, dan (5) memberi maaf.

\section{PEMBAHASAN}

Jenis tindak tutur ilokusi pada pada program gelar wicara Mata Najwa sebagian besar menggunakan tindak tutur yang bervariasi sehingga terjalin komunikasi yang baik dan menarik antara presenter dan narasumbernya. Hal ini sesuai dengan pendapat Wijana (1996:45) dan Apriastuti (2017:40) bahwa tindak tutur sebagai komponen penting dalam kegiatan berbahasa apabila menghasilkan pemahaman dan terjalinnya komunikasi yang baik antara penutur dan lawan tutur akan menghasilkan wacana yang manarik untuk dibaca atau didengar.

Jenis tindak tutur yang ada, yaitu tintak tutur ekspresif, asertif, direktif, komisif, dan deklaratif (Kentary dkk., 2015:64). Tindak tutur ekspresif yang berisi ucapan selamat, terima kasih, memuji, dan mengkritik. Tindak tutur asertif bertujuan untuk mengatakan, melaporkan, dan menyebutkan. Tindak tutur direktif berisi tuturan 
menyuruh, memohon, menuntut, menyarankan, dan menentang. Tindak tutur komisif berisi tentang tuturan berjanji, bersumpah, dan mengancam. Kemudian, tindak tutur deklaratif berisi tentang tuturan memutuskan, membatalkan, melarang, mengizinkan, dan memberi maaf. Dari hasil penelitian ini, menunjukkan bahwa dalam membuat program gelar wicara atau talk show sebaiknya menggunakan variasi tindak tutur ilokusi dan persentase penggunaannya yang paling dominan sebaiknya menggunakan tindak tutur ekspresif sehingga acara lebih manarik. Untuk lebih jelasnya akan dibahas satu per satu jenis tindak tutur ilokusi dalam acara Mata Najwa sebagai berikut.

\section{a. Tindak Tutur Asertif Acara Mata Najwa Edisi Bulan Desember 2018}

Pada acara Mata Najwa edisi bulan Desember tindak tutur asertif ditemukan kutipan dialog yang mengenai tindak tutur asertif. Uraian dari analisis dapat dilihat pada tabel berikut:

Tabel 1. Tindak Tutur Asertif Acara Mata Najwa Edisi Bulan Desember 2018

\begin{tabular}{|c|c|c|c|}
\hline No. & Tindak Tutur & Profil yang Digunakan & Kutipan yang Ditemukan \\
\hline 1 & \multirow{3}{*}{ Asertif } & Mengatakan & 10 kutipan \\
\hline 2 & & Melaporkan & 14 kutipan \\
\hline 3 & & Menyebutkan & 4 kutipan \\
\hline
\end{tabular}

\section{1) Mengatakan}

Tindak tutur mengatakan merupakan tindak tutur yang dilakukan penutur dalam mengujarkan suatu tuturan dengan tujuan untuk mengatakan kepada mitra tutur supaya melakukan sesuatu. Untuk lebih jelasnya dapat diperhatikan pada data berikut:

\section{Data: MN/DBKC/01}

Konteks

NS : Selamat malam selamat datang di Mata Najwa, saya Najwa Sihab tuan rumah Mata Najwa. Pemilu bisa membuat kawan menjadi lawan pindah partai bisa dilakukan dengan ringan, apalagi dalam urusan pilpres yang amat mahal sangat biasa kader-kader malah sibuk menyempal, buat apa bertahan jika tak ada kesempatan apalagi jika ada tawaran yang menggiurkan. Itulah kalkulasi politik yang tak terhindarkan dalam lanskah politik perebutan kekuasaan. Masih bisakah publik mempercayai para jurkam jika mereka sendiri mudah ganti seragam. Inilah Mata Najwa "Barisan Para Mantan".

Kutipan ini menunjukkan tindak tutur asertif. Tindak tutur asertif merupakan tindak tutur yang mengikat penuturnya pada kebenaran dari apa yang dituturkan. Tindak tutur ini disampaikan dengan tujuan untuk mengatakan. Kutipan di samping dikatakan tindak tutur asertif diperkuat dengan kalimat berikut "Itulah kalkulasi politik yang tak terhindarkan dalam lanskah politik perebutan kekuasaan." Penutur menyebutkan suatu kebenaran atas pernyataannya.

\section{2) Melaporkan}

Melaporkan adalah tindak tutur yang menjelaskan atau memberitau apa yang dilakukan. Tindak tutur 'melaporkan' adalah tindak tutur yang disampaikan oleh penutur untuk memberitahukan sesuatu yang terjdi. Untuk dapat memahami hal tersebut dapat diperhatikan pada data berikut: 


\section{Data: MN/DBKC/02}

Konteks

NS : Yak memang tak ada kawan dan lawan abadi dalam politik. Eeem..istilahitu tergambar dalam peta politik lima tahunan jelang pilpres. Mantan kawan bisa jadi lawan begitu pula sebaliknya dan untuk mendengarkan kisah para mantan, hari ini Mata Najwa mengundang sejumlah politikus yang memilih meninggalkan cintanya yang lama dalam dukungan pilpres 2019. Sudah hadir saya perkenalkan satu per satu ini ada Ketua TKN (Tim Kampanye Nasional) Jawa Barat Kang Dedik Mulyadik. "Selamat Malam

Kutipan di samping merupakan tindak tutur asertif, dapat dilihat dengan adanya kalimat yang memberitahu kepada mitra tuturnya pada kutipan berikut "Sudah hadir saya perkenalkan satu per satu ini ada Ketua TKN (Tim Kampanye Nasional) Jawa Barat Kang Dedik Mulyadik."

\section{3) Menyebutkan}

Menyebutkan dapat menyatakan suatu tindakan, keberadaan, ataupun sebuah pengalaman. Tindak tutur menyebutkan adalah tindak tutur yang dilakukan penutur yang menginginkan mitra tutur untuk mengetahui apa yang terjadi. Contoh kutipan terdapat pada kode di bawah ini:

\section{Data: MN/DBKC/02}

Konteks

NS : Terima kasih sudah hadir. Supaya jelas dulu kang dedi ini dulu timsesnya pak prabowo di pemilu lima tahun lalu.

Kutipan tersebut merupakan bagian dari tindak tutur. Tindak tutur yang terdapat di dalam kutipan tersebut adalah tindak tutur asertif. Dikatakan termasuk ke dalam tindak tutur asertif karena penutur memberitahu kepada mitra tuturnya yang dapat dilihat dari kutipan ini "Supaya jelas dulu kang dedi ini dulu timsesnya pak prabowo di pemilu lima tahun lalu."

\section{b. Tindak Tutur Direktif Acara Mata Najwa Edisi Bulan Desember 2018}

Pada acara Mata Najwa edisi bulan Desember tindak tutur direktif ditemukan kutipan dialog yang mengenai tindak tutur direktif. Tindak tutur direktif secari rinci dapat dilihat pada tabel di bawah ini:

Tabel 2. Tindak Tutur Direktif Acara Mata Najwa Edisi Bulan Desember 2018

\begin{tabular}{|c|c|c|c|}
\hline No. & Tindak Tutur & Profil yang Digunakan & Kutipan yang Ditemukan \\
\hline 1 & \multirow{5}{*}{ Direktif } & Menyuruh & 4 kutipan \\
\hline 2 & & Memohon & 3 kutipan \\
\hline 3 & & Menuntut & 5 kutipan \\
\hline 4 & & Menyarankan & 5 kutipan \\
\hline 5 & & Menentang & 6 kutipan \\
\hline
\end{tabular}

\section{1) Menyuruh}

Tindak tutur menyuruh merupakan tindak tutur yang dilakukan penutur dalam mengujarkan suatu tuturan dengan tujuan untuk memerintahkan mitra tutur supaya melakukan sesuatu. Penutur melakukan Untuk lebih jelasnya dapat diperhatikan pada data berikut: 


\section{Data: MN/DBKC/44}

\section{Konteks}

NS : Jadi, saya ingin menggali satu per satu dulu. Apa alasan pribadi kenapa pindah ke lain hati dan saya ingin ke Bang Ferdinan dulu?

Tindak tutur direktif merupakan tindak tutur yang dilakukan penuturnya dengan maksud agar mitra tuturnya melakukan atau memberikan respons terhadap penutur atas apa yang disebutkan di dalam tuturan tersebut. Kutipan di atas merupakan tuturan yang termasuk ke dalam tindak tutur direktif. Hal ini dikarenakan penutur meminta mitra tutur untuk melakukan sesuatu. Kutipan berikut akan memperjelas bahwa tuturan tersebut termasuk ke dalam tindak tutur direktif "Jadi, saya ingin menggali satu per satu dulu." Kata "Ingin" memperjelas tuturan agar mitra tutur merespon dengan melakukan tindakan yang dilakukan melalui kata-kata.

\section{2) Memohon}

Memohon adalah minta dengan santun secara hormat atau berharap supaya mendapat sesuatu. Tindak tutur memohon merupakan tindak tutur yang dilakukan oleh penutur untuk meminta dengan hormat atau berharap supaya mendapat sesuatu dari mitra tutur. Untuk dapat memahami jenis tindak tutur ini dapat diperhatikan pada data berikut:

\section{Data: MN/DBKC/054}

\section{Konteks}

DM : Kita tidak mungkin memperjuangkan sesuatu hanya berdasarkan printah partei, kalo hanya berdasarkan printah partei kan biasanya ia di depan tidak di belakang tetapi kalo di dorong oleh sebuah hati nurani dan kepentingan publik yang lebih luas maka kita akan bekerja secara optimal. Liat saja nanti kinerja dan hasil yang diraih tanggal 17 April liatny jangan diterawang sekarang.

Tindak tutur direktif merupakan tindak tutur yang dilakukan penuturnya dengan maksud agar mitra tuturnya melakukan atau memberikan respons terhadap penutur atas apa yang disebutkan di dalam tuturan tersebut. Kutipan di atas merupakan tuturan yang termasuk ke dalam tindak tutur direktif. Hal ini dikarenakan penutur meminta mitra tutur untuk melakukan sesuatu. Kutipan di samping penutur memberikan saran. Dapat dilihat dari kutipan ini "kalo di dorong oleh sebuah hati nurani dan kepentingan publik yang lebih luas maka kita akan bekerja secara optimal." Meskipun tidak diperjelas dengan adanya kata "Sebaiknya", namun kutipan ini terkesan memberikan saran kepada mitra tuturnya.

\section{3) Menuntut}

Tindak tutur yang disampaikan oleh penutur untuk menyatakan suatu tindaka, pengalaman atau hal lainnya. Penutur meminta lawan tutur untuk memenuhi apa yang diinginkan. Untuk memahami jenis tindak tutur menuntut dapat diperhatikan pada data berikut:

\section{Data: MN/DBKC/48}

\section{Konteks}

NS : Terima kasih anda terus di Mata Najwa "Barisan Para Mantan". Saya ingin ke Kang Dedik, Kang Dedik anda dulu di 2014 ee tim kampanye Pak Prabowo dan sekarang anda ketua tim kampanye Pak Jokowi di Jawa Barat. E dari kacamata anda selaku mantan pemimpin daerah, siapa sih yang lebih jago ngurus pemerintahan, yang akan lebih jago ngurus negara apakah Pak Prabowo atau Pak Jokowi? 
Tindak tutur direktif merupakan tindak tutur yang dilakukan penuturnya dengan maksud agar mitra tuturnya melakukan atau memberikan respons terhadap penutur atas apa yang disebutkan di dalam tuturan tersebut. Kutipan di samping merupakan tuturan yang termasuk ke dalam tindak tutur direktif. Hal ini dikarenakan penutur meminta mitra tutur untuk melakukan sesuatu. Kutipan berikut akan memperjelas bahwa tuturan tersebut termasuk ke dalam tindak tutur direktif "Saya ingin ke Kang Dedik, Kang Dedik anda dulu di 2014 ee tim kampanye Pak Prabowo dan sekarang anda ketua tim kampanye Pak Jokowi di Jawa Barat." Kata "Ingin" memperjelas tuturan agar mitra tutur menuntut dengan melakukan tindakan yang dilakukan melalui kata-kata.

\section{4) Menyarankan}

Menyarankan adalah memberikan saran atau pendapat kepada seseorang untuk dipertimbangkan. Tindak tutur menyarankan adalah tindak tutur yang dilakukan oleh penutur dalam mengujarkan sesuatu dengan tujuan untuk memberikan saran atau pendapat kepada mitra tutur untuk dipertimbangkan. Untuk memahaminya dapat diperhatikan pada data berikut:

\section{Data : MN/DBKC/045 \\ Konteks}

NS : Itu sikap politik anda, yang tentunya sah-sah saja tapi kita ingin juga mengingatkan publik apa sikap politik anda sebelum ini kita lihat cuplikannya.

Kutipan di atas merupakan tuturan direktif. Tuturan direktif dalam kutipan tersebut penutur mencoba mengajak mitra tuturnya untuk merespons dari tuturannya, respons yang diinginkan berupa kata-kata dari mitra tutur. Berdasarkan kutipan tersebut dapat diperkuat bahwa kutipan termasuk dalam tindak tutur direktif yaitu dari kutipan "kita ingin juga mengingatkan publik apa sikap politik anda sebelum ini kita lihat cuplikannya."

\section{5) Menentang}

Menentang adalah merupakan tidak sependapat dengan apa yang dikatkan dengan lawan tutur. Tindak tutur tidak menyetujui adalah tindak tutur yang disampaikan oleh penutur karena tidak sependapat dengan apa yang disampaikan. Untuk memahami jenis tindak tutur menentang dapat diperhatikan pada data berikut:

\section{Data : MN/DBKC/046 \\ Konteks}

NS : Dan baik dan sekarang anda mendukung pak prabowo lagi lagi saya ingin menggali alasan dan kemudian saya akan minta yang lain e e e bicara alasan personalnya dan sekarang pak prabowo bisa melakukan apa yang tidak dilakukan oleh pak Jokowi.

Kutipan di atas termasuk ke dalam tuturan direktif. Tindak tutur direktif merupakan tuturan yang disampaikan oleh penutur kepada mitra tuturnya dengan tujuan agar mitra tutur dapat merespon tuturan tersebut dengan kata-kata. Tuturan direktif ini dapat dilihat dari kutipan "saya ingin menggali alasan dan kemudian saya akan minta yang lain e e e bicara alasan personalnya dan sekarang pak prabowo bisa melakukan apa yang tidak dilakukan oleh pak jokowi." Berdasarkan kutipan tersebut penutur menanyakan sesuatu kepada mitra tuturnya agar mitra tutur menjawab dan memberikan sebuah alasan. Tuturan direktif yang ada dalam kutipan ini juga diperkuat dengan kata "Ingin" dan "Minta". 


\section{c. Tindak Tutur Ekspresif Acara Mata Najwa Edisi Bulan Desember 2018}

Pada acara Mata Najwa edisi bulan Desember tindak tutur ekspresif ditemukan kutipan dialog yang mengenai tindak tutur ekspresif. Tabel di bawah ini dapat menjelaskan hasil analisis:

Tabel 3. Tindak Tutur Ekspresif Acara Mata Najwa Edisi Bulan Desember 2018

\begin{tabular}{|c|c|c|c|}
\hline No. & Tindak Tutur & Profil yang Digunakan & Kutipan yang Ditemukan \\
\hline 1 & \multirow{4}{*}{ Ekspresif } & Ucapan selamat & 9 kutipan \\
\hline 2 & & Ucapan Terima kasih & 5 kutipan \\
\hline 3 & & Memuji & 4 kutipan \\
\hline 4 & & Mengkritik & 14 kutipan \\
\hline
\end{tabular}

\section{1) Ucapan Selamat}

Mengucapkan selamat adalah doa, ucapan, pernyataan, dan sebagainya yang mengandung harapan supaya sejahtera, beruntung, tidak kurang suatu apa. Tindak tutur mengucapkan selamat adalah tindak tutur yang disampaikan oleh penutur berupa doa, ucapan, pernyataan, dan sebagainya yang mengandung harapan supaya sejahtera, beruntung, tidak kurang suatu apa. Hal ini menunjukkan bahwa tindak tutur ekspresif dalam bentuk ucapan selamat memberikan dampak positif pada motivasi pada lawan tutur (Murti dkk., 2018-17-18). Untuk memahami jenis tindak tutur ini dapat diperhatikan pada data berikut:

\section{Data: MN/DBKC/072}

Kritik

NS: Selamat malam selamat datang di Mata Najwa, saya Najwa Sihab tuan rumah Mata Najwa. Pemilu bisa membuat kawan menjadi lawan pindah partai bisa dilakukan dengan ringan, apalagi dalam urusan pilpamat mahal sangat biasa kader-kader malah sibuk menyempal, buat apa bertahan jika tak ada kesempatan apalagi jika ada tawaran yang menggiurkan. Itulah kalkulasi politik yang tak terhindarkan dalam lanskah politik perebutan kekuasaan. Masih bisakah publik mempercayai para jurkam jika mereka sendiri mudah ganti seragam. Inilah Mata Najwa "Barisan Para Mantan".

Kutipan di atas termasuk dalam bagian tuturan ekspresif karena penutur memberikan ekspresi kepada mitra tuturnya dengan memberikan ucapan selamat. Dapat dilihat dari kutipan berikut untuk memperjelasnya "Selamat malam selamat datang di Mata Najwa”.

\section{2) Ucapan Terima Kasih}

Berterima kasih adalah mengucap syukur atau melahirkan rasa syukur atau membalas budi setelah menerima kebaikan. Tindak tutur berterima kasih adalah tindak tutur yang disampaikan oleh penutur untuk mengucap syukur atau melahirkan rasa syukur atau membalas budi setelah menerima kebaikan, dan sebagainya dari seseorang. Untuk memahami jenis tindak tutur berterima kasih dapat diperhatikan pada data berikut:

\section{Data: MN/DBKC/075}

\section{Konteks}

NS: Terima kasih sudah hadir. Supaya jelas dulu kang dedi ini dulu timsesnya pak prabowo di pemilu lima tahun lalu.

Tuturan ini merupakan tindak tutur ekspresif, penutur memberikan ucapan terima kasih kepada mitra tuturnya, dilihat dari kutipan berikut "Terima kasih sudah hadir." Ucapan terima kasih tersebut merupakan ekspresi penutur yang disesuaikan dengan apa yang dirasakan oleh penutur. 


\section{3) Memuji}

Memuji merukan suatu pernyataan yang ditunjukan kepada seseorang karena telah melakukan pekerjaan yang baik. Tindak tutur memuji adalah tindak tutur yang disampaikan oleh penutur berupa kebaikan atu penghargaan terhadap sesuatu, ungkapan rasa bangganya atau senang terhadap pekerjaan yang dilakukan. Untuk memahami jenis tindak tutur ini dapat diperhatikan pada data berikut:

\section{Data: MN/PPKLH/087}

\section{Konteks}

DM : Yang dulu dijual kan Pak Prabowo relatif e seorang pemimpin militer waktu itu yang memiliki daya magnetik yang cukup kuat bagi rakyat Jawa Barat pada waktu itu. Nah kemudian rakyat Jawa Barat itu memang pada waktu itu sangat suka terhadap pemimpin-pemimpin yang memiliki basic militer dan sikap-sikap yang relatif disukai secara umum yang be berdasarkan penampilan.

Tindak tutur ekspresif merupakan tindak tutur yang mengungkapkan sikap psikologis penutur terhadap suatu keadaan. Kutipan di samping termasuk ke dalam tuturan ekspresif dikarenakan penutur memuji orang yang dibicarakannya dalam situasi memuji pada tuturan tersebut.

\section{4) Mengkritik}

Mengkritik adalah memberikan pertimbangan baik dan buruk, salah atau benar terhadap satu hal dengan tujuan adanya perbaikan. Tindak tutur mengkritik adalah tindak tutur yang disampaikan oleh penutur berupa pertanyaan yang detail untuk mendapatkan pemahaman yang jelas. Untuk memahami jenis tindak tutur ini dapat diperhatikan pada data berikut:

\section{Data: MN/ BJVP /091}

\section{Konteks}

DM : Bukan begitu ketika orang belanja kita tu sudah tau berapa harga yang ada di warung itu jadi ini gak ada problem sebenarnya kemudian kalo ada yang bicara setiap hari ngeluh, yang ngeluh itu kan di media sosial dan rata-rata orang yang berkemampuan ekonomi.

Tindak tutur ekspresif merupakan tindak tutur yang mengungkapkan sikap psikologis penutur terhadap suatu keadaan. Kutipan di samping termasuk ke dalam tuturan ekspresif dikarenakan penutur mengelak dari pernyataan yang dibicarakannya dalam situasi tutur tersebut. Kutipan ini diperjelas dengan adanya kutipan "Bukan begitu ketika orang belanja kita tu sudah tau berapa harga yang ada di warung itu".

\section{5) Mengkritik}

Mengkritik adalah memberikan pertimbangan baik dan buruk, salah atau benar terhadap satu hal dengan tujuan adanya perbaikan. Tindak tutur mengkritik adalah tindak tutur yang disampaikan oleh penutur berupa pertanyaan yang detail untuk mendapatkan pemahaman yang jelas. Untuk memahami jenis tindak tutur ini dapat diperhatikan pada data berikut:

\section{Data: MN/ BJVP /091}

\section{Konteks}

DM : Bukan begitu ketika orang belanja kita tu sudah tau berapa harga yang ada di warung itu jadi ini gak ada problem sebenarnya kemudian kalo ada yang bicara setiap hari ngeluh, yang ngeluh itu kan di media sosial dan rata-rata orang yang berkemampuan ekonomi.

Tindak tutur ekspresif merupakan tindak tutur yang mengungkapkan sikap psikologis penutur terhadap suatu keadaan. Kutipan di atas termasuk ke dalam 
tuturan ekspresif dikarenakan penutur mengelak dari pernyataan yang dibicarakannya dalam situasi tutur tersebut. Kutipan ini diperjelas dengan adanya kutipan "Bukan begitu ketika orang belanja kita tu sudah tau berapa harga yang ada di warung itu".

\section{d. Tindak Tutur Komisif Acara Mata Najwa Edisi Bulan Desember 2018}

1) Bersumpah

Bersumpah dinyatakan atau diucapkan secara resmi dengan bersaksi kepada Tuhan. Untuk menguatan kebenaran dan kesungguhannya. Tindak tutur 'bersumpah' adalah tindak tutur yang disampaikan oleh penutur untuk meyakinkan kepada mitra tutur. Untuk dapat memahami hal tersebut dapat diperhatikan pada data berikut:

\section{Data: MN/DBKC/0104}

Konteks

FH : Oh tidak! Jauh sekali. Jauh sekali.

Kutipan di atas merupakan tindak tutur komisif yang ditandai dengan kata-kata "Oh tidak!" sehinga tampak dengan jelas bahwa penutur memberikan penolakan kepada mitra tuturnya.

\section{2) Mengancam}

Mengancam sebuah perkataan yang dapat menanyakan suatu tindakan, keberadaan. Tindak tutur 'mengancam' adalah tindak tutur yang disampaikan oleh penutur untuk menyatakan maksud, niat atau rencana melakukan sesuatu. Untuk dapat memahami hal tersebut dapat diperhatikan pada data berikut:

\section{Data: MN/DBKC/0109}

Konteks

FA : Wow gak bisa.

Tuturan pada kutipan "Wow gak bisa." merupakan suatu bentuk tindak tutur yang melakukan penolakan kepada mitra tutur. Tuturan ini merupakan salah satu bentuk tindak tutur komisif.

\section{e. Tindak Tutur Deklarasi Acara Mata Najwa Edisi Bulan Desember 2018}

Pada acara Mata Najwa edisi bulan Desember tindak tutur deklarasi ditemukan kutipan dialog yang mengenai tindak tutur deklarasi. Pada tabel di bawah ini akan dijelaskan sebagai berikut:

Tabel 4.Tindak Tutur Deklarasi Acara Mata Najwa Edisi Bulan Desember 2018

\begin{tabular}{|c|c|c|c|}
\hline No. & Tindak Tutur & Profil yang Digunakan & Kutipan yang Ditemukan \\
\hline 1 & \multirow{4}{*}{ Deklaratif } & Memutuskan & 2 kutipan \\
\hline 2 & & Membatalkan & 2 kutipan \\
\hline 3 & & Melarang & 1 kutipan \\
\hline 4 & & Memberi Maaf & 0 kutipan \\
\hline
\end{tabular}

\section{1) Memutuskan}

Memutuskan memiliki arti dapat menyatakan suatu tindakan, keberadaan ataupun pengalaman. Tindak tutur 'memtuskan' adalah tindak tutur yang disampaikan oleh penutur untuk melakukan sebuah tindakan kepada mitra tutur melakukan sesuatu. Untuk dapat memahami hal tersebut dapat diperhatikan pada data berikut: 


\section{Data: MN/DBKC/0114}

Konteks

$\mathrm{FH}$ : Saya begini dalam sebuah situasi seperti ini tentu saya tidak punya harapan lagi kepada pak Jokowi saya harus melabuhkan harapan saya pada sosok yang baru sedang istilahnya berjudi saya tidak mungkin meneruskan perjudian yang sudah kalah lebih bagus pindah lapak yang baru. Kan itu yang saya asumsikan.

Tuturan tersebut merupakan tuturan yang termasuk ke dalam jenis tindak tutur deklarasi. Karena tuturan ini menunjukkan bahwa penutur memutuskan sesuatu yang disampaikan kepada mitra tuturnya. Bukti tuturan terdapat pada kutipan berikut "saya harus melabuhkan harapan saya pada sosok yang baru".

\section{2) Membatalkan}

Membatalkan adalah menyatakan sesuatu hal yang tidak terjadi, atau menyatakan batal atau tidak sah. Tindak tutur 'membatalkan' adalah tindak tutur yang disampaikan oleh penutur untuk membatkan suatu hal atau suatu tindakan tindakan kepada mitra tutur untuk tidak melakukan sesuatu. Untuk dapat memahami hal tersebut dapat diperhatikan pada data berikut:

\section{Data: MN/DBKC/0115}

\section{Konteks}

FA : Itulah yang saya tidak mau pilih a a a pak Prabowo, kenapa itu arogansi kekuasaan ini otonomi Bung, sudah ada delegasi otoriti.

Tuturan di atas salah satu bagian dari tindak tutur deklarasi, karena penutur menyatakan keputusannya yang tidak mau memilih Prabowo. Hal tersebut diperkuat dengan adanya kutipan berikut "Itulah yang saya tidak mau pilih a a a pak Prabowo" pernyataan tidak mau tersebut disampaikan penutur kepada mitra tutur terhadap keputusannya, tampak meragukan dan seperti membatalkan.

\section{3) Melarang}

Melarang adalah memerintahkan agar tidak melakukan sesuatu atau memperbolehkan berbuat sesuatu tindak tutur 'melarang' adalah tindak tutur yang disampaikan oleh penutur untuk mencegah mitra tutur melakukan sesuatu. Untuk dapat memahami hal tersebut dapat diperhatikan pada data berikut:

\section{Data: MN/PPKLH/0118}

\section{Konteks}

NS: Jangan diterawang sekarang ya. Baik, saya ingin ke ke Pak Tedjo. Pak Tedjo, Anda mantan e mentri kabinet Jokowi menkopolhukam anda dulu dan sekarang anda ee wakil ketua dewan penasehat barisan pemenangan Prabowo-Sandiaga. Ee kalo ada yang mengatakan pak, ini pindah haluan karna sakit hati dirisyafel apakah tuduhan itu berlebihan atau ada benarnya?

Kutipan di atas merupakan tuturan deklarasi, tindak tutur ini memberikan suatu larangan kepada mitra tutur. Larangan tersebut dapat dilihat dari adanya kata "jangan" dalam tuturan tersebut. Dari hasil penelitian ini, menunjukkan bahwa dalam membuat program gelar wicara atau talk show sebaiknya menggunakan variasi tindak tutur ilokusi dan persentase penggunaannya yang paling dominan sebaiknya menggunakan tindak tutur ekspresif sehingga acara lebih manarik dan bisa mempersuasi penonton. 


\section{KESIMPULAN DAN SARAN}

Tindak Tutur pada acara Mata Najwa Edisi Bulan Desember 2018 menggunakan variasi ilokusi, yaitu tindak tutur asertif, direktif, komisif, ekspresif dan deklarasi. Bahasa yang paling banyak ditemkan lebih dominan pada tindak tutur ekspresif. Jumlahnya lebih banyak ditemukan yaitu 42 kutipan tindak tutur ekspresif tentang ucapan selamat, terima kasih, memuji, dan mengkritik. Tindak tutur asertif terdapat beberapa bagian yaitu mengatakan, melaporkan, dan menyebutkan. Secara rinci dapat dijelaskan tindak tutur bagian asertif tentang mengatakan terdapat 10 kutipan. Tindak tutur asertif bagian malaporkan terdapat 14 kutipan dialog. Tindak tutur asertif yang terakhir tentang menyebutkan terdapat 4 kutipan dialog.

Tindak tutur direktif pada acara Mata Najwa Edisi Bulan Desember 2018 terdapat beberapa bagian yaitu menyuruh, memohon, menuntut, menyarankan, dan menentang. Secara rinci dapat dijelaskan tindak tutur bagian direktif tentang menyuruh terdapat 4 kutipan. Tindak tutur direktif bagian memohon terdapat 3 kutipan dialog. Tindak tutur direktif tentang menuntut terdapat 5 kutipan dialog. Tindak tutur direktif bagian menyarankan terdapat 6 kutipan diaolg, dan terakhir bagian menentang terdapat 6 kutipan dialog. Tindak tutur ekspresif pada acara Mata Najwa Edisi Bulan Desember 2018. Tindak tutur ekspresif terdapat beberapa bagian diantaranya yaitu ucapan selamat, terima kasih, memuji, dan mengkritik. Secara rinci dapat dijelaskan tindak tutur bagian ekspresif tentang ucapan selamat terdapat 9 kutipan. Tindak tutur ekspresif bagian terima kasih terdapat 5 kutipan dialog. Tindak tutur ekspersif tentang memuji terdapat 4 kutipan dialog. Tindak tutur ekspesif bagian mengkritik terdapat 14 kutipan diaolg.

Tindak tutur komisif pada acara Mata Najwa Edisi Bulan Desember 2018 terdapat beberapa bagian yaitu berjanji, bersumpah, dan mengancam. Secara rinci dapat dijelaskan tindak tutur bagian komisif tentang berjanji terdapat 2 kutipan. Tindak tutur komisif bagian bersumpah terdapat 3 kutipan dialog. Tindak tutur komisif tentang mengacam terdapat 1 kutipan dialog. Kemudian, tindak tutur deklarasi pada acara Mata Najwa Edisi Bulan Desember 2018 terdapat beberapa bagian yaitu memutuskan, membatalkan, melarang, mengizinkan, dan memberi maaf. Secara rinci dapat dijelaskan tindak tutur bagian deklarasi tentang memutuskan terdapat 2 kutipan. Tindak tutur deklarasi bagian membatalkan terdapat 2 kutipan dialog. Tindak tutur deklarasi tentang melarang terdapat 1 kutipan dialog. Tindak tutur deklarasi bagian mengizinkan dan memberi maaf tidak ditemukan dalam kutipan dialog. Dalam membuat program gelar wicara atau talk show sebaiknya menggunakan variasi tindak tutur ilokusi dan persentase penggunaannya yang paling dominan sebaiknya menggunakan tindak tutur ekspresif sehingga acara lebih manarik dan bisa mempersuasi penonton.

\section{DAFTAR PUSTAKA}

Apriastuti, N. N. A. A. (2017). Bentuk, Fungsi, dan Jenis Tindak Tutur dalam Komunikasi Siswa di Kelas IX Unggulan SMP PGRI 3 Denpasar. Jurnal IImiah Pendidikan dan Pembelajaran, 1(1). 40.

Ardianto, A. (2013). Tindak Tutur Direktif Guru dalam Wacana Interaksi Kelas Anak Tunarungu. Litera, 12(1). https://doi.org/10.21831/ltr.v12i01.1318 
Chaer, A. (2010). Kesanunan Berbahasa. Jakarta: Rineka Cipta.

Commings, L. (2007). Pragmatik Sebuah Perspektif Multisiplener. Yogyakarta: Pustaka Pelajar.

Handayani, T. K. (2016). Nilai-Nilai Karakter dalam Tindak Tutur Ilokusi dalam Buku Wir Besuchen Eine Moschee. Litera, 15(2), https://doi.org/10.21831/ltr.v15i2.11831

Insani, E. N., \& Sabardila, A. (2016). Tindak Tutur Perlokusi Guru dalam Pembelajaran Bahasa Indonesia Kelas XI SMK Negeri 1 Sawit Boyolali. Jurnal Penelitian Humaniora, 17(2), 176. doi:10.23917/humaniora.v17i2.2509

Kentary, A., Ngalim, A., \& Prayitno, H. J. (2015). Tindak Tutur llokusi Guru Berlatar Belakang Budaya Jawa: Perspektif Gender. Jurnal Penelitian Humaniora, 16(1), https://doi.org/10.23917/humaniora.v16i1.1522

Kusmiarti, R., Yuniati, I., \& Noermanzah. (2020). Improving Student Communication Skills In Learning Indonesian Language Through Collaborative Learning. Retrieved from osf.io/9km3u. International Journal of Scientific and Technology Research, 9(1).

Lismayanti, H., \& Aswadi, D. (2018). Tindak Tutur Lokusi Pedagang dan Pembeli di Pasar Sudi Mampir Banjarmasin. STILISTIKA: Jurnal Bahasa, Sastra, Dan Pengajarannya, 3(1). 101, doi:10.33654/sti.v3i1.510

Mirfat, M. (2019). Prinsip Kesantunan dalam Fungsi Tindak Tutur llokusi Film Ein Freund Von Mir dan Kokowääh. Belajar Bahasa, 4(1), 89. doi:10.32528/bb.v4i1.1870

Murti, S., Nisai Muslihah, N., \& Permata Sari, I. (2018). Tindak Tutur Ekspresif dalam Film Kehormatan di Balik Kerudung Sutradara Tya Subiakto Satrio. Silampari Bisa: Jurnal Penelitian Pendidikan Bahasa Indonesia, Daerah, dan Asing, 1(1), 17-18. doi:10.31540/silamparibisa.v1i1.7

Noermanzah, N. (2019). Bahasa sebagai Alat Komunikasi, Citra Pikiran, dan Kepribadian. Seminar Nasional Pendidikan Bahasa dan Sastra, Prosiding Seminar Nasional Bulan Bahasa (Semiba) 2019, https://ejournal.unib.ac.id/index.php/semiba/article/view/11151

Novianti, H. (2017). Analisis Tindak Tutur Ilokusi Iklan Perdagangan di Radio Harau FM Payakumbuh Periode Pebruari-April 2016. Bahastra, 37(2), 129. doi:10.26555/bahastra.v37i2.7493

Saptani, P. (2015). Tindak Tutur dalam Wacana Kelas Vb SD Negeri 62 Kota Bengkulu Tahun Pelajaran 2012/2013. Diksa: Pendidikan Bahasa Dan Sastra Indonesia, 1(2), 1-2. doi:10.33369/diksa.v1i2.3145

Sudaryat, Y. (2011). Makna dalam Wacana. Bandung: Yrama Widya. 
Syafryadin, Dian, E. C. Wardhana., Eka Apriani., \& Noermanzah. (2020). Maxim Variation, Conventional, and Particularized Implicature on Students' Conversation. International Journal of Scientific and Technology Research, 9(2) https://doi.org/10.31219/osf.io/cza8y.

Wijana, I. D. P. (1996). Dasar-dasar Pragmatik. Yogyakarta: Andi Yogyakarta.

Wijana, I. D. P. dan Rohmadi, M. (2011). Analisis Wacana Pragmatik. Surakarta:Yuma Pustaka. 